\title{
Desafios do RH estratégico
}

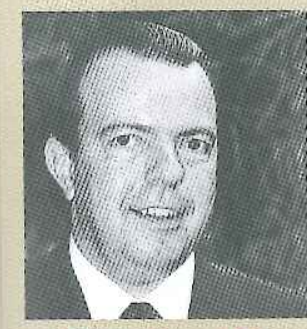

Sérgio Amad Costa FGV-EAESP

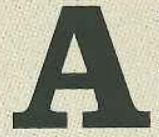
té alguns anos atrás, a área de RH das empresas podia ser definida usando-se basicamente a "metáfora espacial": era um departamento, tinha uma localizaçāo fixa e uma função de centralização de políticas e práticas. Assim, quando surgia um problema que envolvesse recursos humanos na empresa, era necessário chamar o "especialista de RH". Por exemplo, se um gerente de fábrica percebesse uma queda na motivação de seu pessoal, ele imediatamente recorreria ao $\mathrm{RH}$, transferindo a essa área a responsabilidade pela solução do problema.

A principal consequência desse modus operandi era que a gestão da empresa ficava dividida entre os que sabiam "lidar com gente" os especialistas de $\mathrm{RH}-\mathrm{e}$ os que sabiam "lidar com os negócios" - os gerentes de linha. Essa dicotomia perdurou um bom tempo, e gerou duas consequências: primeiro, afastou a área de RH da estratégia do negócio; segundo, distanciou os gerentes de linha das práticas de gestão de pessoas. Manteve-se porque era um arranjo confortável para as partes envolvidas, enquanto a competição não obrigou a uma evolução das práticas de gestão de pessoas.

Esse frágil equilíbrio começou a ruir quando ganhou força a idéia de que não existe uma área exclusiva de gestão de pessoas, mas que todos na organização, principalmente os gerentes de linha, têm de gerir os recursos humanos. Com isso, ganhou espaço a figura do novo gestor, que administra negócios e pessoas, e emergiu o RH descentralizado, com um papel estratégico junto aos negócios.

Muitas organizaçōes evoluíram nesse sentido, e não são raras as que já operam segundo esses princípios há mais de 10 anos. Porém, se o discurso é coerente e está bem disseminado entre profissionais de $\mathrm{RH}$, o mesmo não se pode dizer da prática. Ao observar a realidade organizacional, constatamos que a teoria, na prática, é outra: primeiro, muitas organizações adotam postura de fachada, promovendo o novo discurso, porém mantendo as antigas práticas centralizadas; segundo, são comuns os casos de gestores despreparados, que não conseguem assumir a responsabilidade de administrar pessoas, gerando um vazio perigoso para a organização; terceiro, em muitos casos a descentralização fez com que o RH se fragmentasse, e se tornasse incapaz de manter seu papel unificador de políticas e princípios; quarto, em algumas empresas, o alinhamento excessivo do RH com os negócios, em uma posição subalterna, fez com que ele perdesse de vista seu caráter humanista, a passasse a ser apenas uma ferramenta menor de gestāo.

O RH estratégico e descentralizado, a trabalhar em parceria com os gerentes de linha, continua sendo o objeto de desejo de muitos profissionais da área. Porém, os que chegaram lá se depararam com novos desafios, que agora devem ser encarados. 